Шедяков В. Е., д.с.н., к.э.н., доцент

независимый исследователь

г. Киев, Украина

DOI: https://doi.org/10.30525/978-9934-26-107-7-7

\title{
ВЗАИМНАЯ ОТВЕТСТВЕННОСТЬ \\ ГОСУДАРСТВА И НАСЕЛЕНИЯ: АКЦЕНТЫ ПЕРИОДА ПОСТКОРОНАВИРУСНОГО ВОССТАНОВЛЕНИЯ
}

Уже очевидно: пандемия обнажила и обострила проблемы отнюдь не только в медицинской и фармацевтической сферах, но и социальной, экономической, нравственной, политической и т.д. Восстановление также требует и мер уврачевания выявленных дисбалансов, и вписывания их в общий контекст межпарадигмальных трансформаций. Подлежит первоочередному совершенствованию сам характер социально-экономического взаимодействия; необходим переход от стремления к господству и принуждению - к взаимопомощи, доверию и солидарной ответственности [1-5]. К примеру, печальны глобальные последствия для ойкумены от попыток: перекупить специалистов и средства индивидуальной защиты, рассматривать вакцины не как шанс на спасение жизней и здоровья, а как на потенциал финансовой и политической агрессии и т.п. Отнюдь не во всех странах уровень проявляемой взаимной ответственности государств и населения адекватен историческим вызовам. Далеко не повсеместно продемонстрированы общественное доверие и взаимопомощь. Зачастую и правительственные меры, и поведение населения колебались в диапазоне от затягивания с объявлением карантина до непомерных строгостей и нагнетания жестокости противостояний.

Между тем, отношение к человеку и к окружающей среде не могут принципиально расходиться; экология человека - значимая часть экологической культуры. Экологическую устойчивость необходимо понимать не как противостоящую экономическому росту, а как условие гармоничного общественного развития. 
Так, становление устойчивого состояния гармоничной социобиологической целостности требует достижения динамичного единства мер обеспечения безопасности и развития. Значительная доля социальных болезней порождается застоем творческой энергии общества, окостенением его политической и хозяйственной системы. Позор регулярных неудач и иррационализация жизни естественны для попыток противостояния логике истории.

Как известно, если на Востоке всегда высоко ценили единство человека и природы, основанную на этом экологическую устойчивость, то на Западе долгое время ставка делалась на обеспечение экономического роста. Ради этого часто уничтожались целые экосистемы, хищнически уничтожались и цивилизации, и опорные для них природные циклы. История колонизации обеих Америк, Азии, Африки и Австралии полны тому примеров. И ныне, очевидно, добыча газа методом гидроразрыва пласта губительна для природы, а ценность жизни человека уничижается погоней за прибылью и монополизацией рынков (очередной пример - поведение фармкорпораций и государств в период пандемии). А вот декларирование «зелёных» лозунгов выступает лишь удобным девизом для борьбы с оппонентами и торможения конкурентов. Безответственное поведение государств, транснациональных корпораций и агрессивных военных блоков очевидным образом связано с жёстким эгоцентризмом их руководства и реальным вытеснением народных масс из политической жизни. Общеизвестное фактическое отсутствие прав и свобод человека и гражданина привычно «компенсируется» тотальным манипулированием, политическими репрессиями во внутреннем курсе и грубым вмешательством во внутренние дела других - во внешней политике.

Ресурсно-ориентированная экономика не может не признавать первоочередного значения экологических факторов безопасности и развития общества, в частности - при изучении обоснованности применения технологий. Реактуализируется классическое разделение собственно разумной «экономики» и «хрематистики» 
неудержимой гонки за наживой. Соответственно, интеграция как в общество, так и в международные союзы строится либо на попытках «введения единообразия» за счёт людоедского желания «вбомбить в демократию» (понимаемую как господство своих эгоистических интересов) непокорных, либо на сохранении разнообразия и несущих его культурно-цивилизационных народов - «пусть расцветают тысячи цветов». Т.о. отход от пронизывающих отживающую модель общественного устройства отношений господства - подчинения к структурам доверия, сотрудничества и сотворчества тесно переплетен с освоением гораздо более гуманных перспектив и, соответственно, движением к новому уровню экологичности. Ойкумена движется от консьюмеризма и / или накопительства, когда ВВП определяется всего лишь массивом уничтоженного сырья, а гонка сверхпотребительства как извращённого стимула лихорадочного производства дополняется громадным массивом массового недопотребления предметов первой необходимости, к творческой (прежде всего, интеллектуально-духовной) активности как форме развёртывания комплекса дарований личности, естественно акцентируя «зелёные» воспроизводственные циклы. Соответственно, экономика включается в качестве подсистемы в природную среду. С одной стороны, это предполагает возврат на новом витке общественного развития к антипотребительству и модели поведения, обеспечивающей удовлетворение лишь базовых сущностных сил, с другой, - переложение существенной их части на общество и государство. Соответственно, новая эпоха благоприятна для ограничения в потребительстве и стяжательстве / накопительстве и требует максимизации социального поля участников творческого процесса. Надлежит принять решительные меры по преодолению пропасти между богатыми и бедными в возможности доступности к общественным благам, вообще - в их укладе жизни [6-12]. 


\section{Литература:}

1. Кропоткин П.А. Этика: Избр. труды. Москва : Политиздат, 1991. 496 с.

2. Шедяков В.Е. Этика взаимодействия сквозь призму перемен. Débats scientifiques et orientations prospectives du développement scientifique: collection de papiers scient. « $\Lambda \mathrm{О} Г О \Sigma$ » avec des matériaux de la I conf. scient. et pratique intern. Paris, 2021. Vol. 4. P. 113-117. DOI: 10.36074/logos-05.02.2021.v4.28.

3. Shedyakov V. Pandemic and change of public paradigm: political and economic aspects of the transition. Pandemic Economic Crisis: Changes and New Challenges to Society / scient.ed. by M. Bezpartochnyi. Sofia: St. Grigorii Bogoslov, 2020. P. 48-60. DOI: https://doi.org/10.5281/zenodo.4396028.

4. Шедяков В.Е. Создание привлекательных условий жизни и благоприятных для творчества предпосылок - цель и условие долгосрочного эндогенного социально-экономического развития при формировании «умного общества». The Development of International Competitiveness: State, Region, Enterprise: Proceed. of Intern. Scient. Conf. Lisbon, 2016. Part II. P. 34-36.

5. Шедяков В.Е. Смена общественной парадигмы в теории и на практике. Advanced discoveries of modern science: experience, approaches and innovations: collection of scient. papers «SCIENTIA» with Proceed. of I Intern. Scient. and Theor. Conf. Amsterdam, 2021. Vol. 2. P. 38-42. DOI: 10.36074/scientia-09.04.2021.

6. Кропоткин П.А. Взаимопомощь как фактор эволюции. Москва : Самообразование, 2007. $240 \mathrm{c}$.

7. Шедяков В.Е. Постглобальные возможности и угрозы: диапазон решений. Economic Development: Global Trends and National Peculiarities / ed. by A. Pawlik, K. Shaposhnykov. Kielce: Baltija Publishing, 2020. P. 261-275. DOI: https://doi.org/10.30525/978-9934-588-61-7-18

8. Куликов Д.Е., Сергейцев Т.Н. Мировой кризис. Восток и Запад в новом веке. Москва : Эксмо, 2017. 496 с.

9. Шедяков В.Е. Глобальные трансформации и совершенствование организационно-управленческих отношений. Virtus. 2021. Issue 50. January. Р. 191-196.

10. Шедяков B.E. Осуществление парадигмальных трансформаций: сорезонирование стратегии, тактики и оперативного искусства в управленческих композициях. Development and modernization of social sciences: experience of Poland and prospects of Ukraine / Maria Curie-Sklodowska University. Lublin : Baltija Publishing, 2017. P. 282-307.

11. Fallaci O. The Rage and the Pride. Universe Publishing, 2002. 187 p.

12. Sarrazin T. Deutschland schafft sich ab. Wie wir unser Land aufs Spiel setzen. München : Deutsche Verlags-Anstalt, 2010. 463 p. 